University of Nebraska - Lincoln

DigitalCommons@University of Nebraska - Lincoln

$6-2000$

\title{
Host Specificity in Metamera sillasenorum, n. sp., a Gregarine Parasite of the Leech Helobdella triserialis with Notes on Transmission Dynamics
}

\author{
Megan R. Wise de Valdez \\ Colorado State University, Megan.Wise@Colostate.Edu \\ John J. Janovy Jr. \\ University of Nebraska - Lincoln, jjanovy1@unl.edu \\ John C. Wise \\ University of Nebraska - Lincoln
}

Follow this and additional works at: https://digitalcommons.unl.edu/bioscijanovy

Part of the Parasitology Commons

Wise de Valdez, Megan R.; Janovy, John J. Jr.; and Wise, John C., "Host Specificity in Metamera sillasenorum, n. sp., a Gregarine Parasite of the Leech Helobdella triserialis with Notes on Transmission Dynamics" (2000). John Janovy Publications. 36.

https://digitalcommons.unl.edu/bioscijanovy/36

This Article is brought to you for free and open access by the Papers in the Biological Sciences at DigitalCommons@University of Nebraska - Lincoln. It has been accepted for inclusion in John Janovy Publications by an authorized administrator of DigitalCommons@University of Nebraska - Lincoln. 


\title{
HOST SPECIFICITY IN METAMERA SILLASENORUM, N. SP., A GREGARINE PARASITE OF THE LEECH HELOBDELLA TRISERIALIS WITH NOTES ON TRANSMISSION DYNAMICS
}

\author{
Megan R. Wise*, J. Janovy, Jr., and John C. Wise \\ School of Biological Sciences, University of Nebraska Lincoln, Lincoln, Nebraska 68688-0118
}

\begin{abstract}
Eugregarines of the suborder Septatorina are apicomplexan parasites that are found mainly in arthropods. Some exceptions are species in the Metameridae that contains the only 5 septate gregarines recorded from annelids. The type genus is Metamera Duke, 1910 with 2 species, Metamera schubergi Duke, 1910, in European Glossiphonia complanata, and Metamera reynoldsi Jones, 1943, from North American G. complanata. Over the summers of 1995-1998, in Keith County, Nebraska, septate gregarines were found in the glossiphoniid leech Helobdella triserialis. The gregarines were determined to be a new species of Metamera, herein named Metamera sillasenorum. Measurements of size and body proportions of over 600 gregarines and 50 oocysts showed differences from measurements of $M$. schubergi and $M$. reynoldsi, and secondary septa in the deutomerite were rarely observed. Field observations indicated that $M$. sillasenorum is probably host specific. In the laboratory, leeches also exhibited strong feeding preferences; e.g., H. triserialis and G. complanata consumed only snails, whereas Helobdella stagnalis consumed only oligochaetes. Infection experiments demonstrated that freshwater snails ingest the oocysts and are required as mechanical vectors. Oocysts were passed unaltered through the snails' intestines. Glossiphonia complanata did not become infected regardless of heavy exposure to oocysts, although only $5 \mathrm{G}$. complanata were used in the experiments. The results show that host specificity of $M$. sillasenorum is most likely due to a combination of host-feeding habits and host-parasite compatibility.
\end{abstract}

The Metameridae (Apicomplexa: Eugregarinida) was established by Levine (1979) to include 5 genera of septate gregarines that exhibit secondary segmentation and that parasitize annelid hosts. Three of the genera are monotypic: Cognetiella legeri (Cognetti de Martiis, 1911) is found in the coelom of the oligochaete Kynotus pitarelli, Deuteromera cleava Bhatia and Setna, 1938 occurs in the intestine of the polychaete Eunice siciliensis, and Gopaleilla marphysae Ganapati, Kalavati, and Sundaram, 1974 is an intestinal parasite of the polychaete Marphysa gravelyi. The type genus Metamera, Duke, 1910 currently includes 2 species, Metamera schubergi Duke, 1910, and Metamera reynoldsi Jones, 1943, both from glossiphoniid leeches. The type host of M. schubergi is the European Glossiphonia complanata (see Levine, 1979), although in the species description, Duke (1910) also listed Hemiclepsis marginata as a host. The type host of $M$. reynoldsi is the North American G. complanata.

During the summers of 1995-1998, a species of septate gregarine was discovered in Helobdella triserialis (Hirudinea: Glossiphoniidae) in western Nebraska. These gregarines are considered to be a new species of Metamera, based on epimerite structure and host. Secondary segmentation was seen in only 2 trophozoites of over 2,000 observed during the 3 summers. The new Metamera species was found only in $H$. triserialis, although Helobdella stagnalis and G. complanata were present in the same pond, an observation suggesting that this parasite might be host specific, although $G$. complanata was exceedingly rare throughout the study period. Host specificity has not been previously observed in leech gregarines (Duke, 1910), but Jones (1943) found $M$. reynoldsi only in G. complanata. However, experimental infections to establish the range of host specificity have not been done in a previous study. Nevertheless, Duke's (1910) observations of $M$. schubergi in both G. complanata and $H$. marginata suggest that Metamera n. sp. from

Received 19 May 1999; revised 30 September 1999; accepted 7 October 1999.

* Current address: Schering-Plough Animal Health, 21401 W. Center Rd., Elkhorn, Nebraska 68022.
Keith County, Nebraska should infect co-occurring confamilial host species. Glossiphonia complanata, $H$. triserialis, and $H$. stagnalis are all members of the Glossiphoniidae (Rhynchobdellida); all 3 are found near the shore of freshwater ponds among vegetation and detritus. Glossiphonia complanata was a logical choice for testing host specificity because it is the type host for both $M$. schubergi and M. reynoldsi. Helobdella stagnalis was also used in the present study because it is presumably most closely related to species $H$. triserialis among the species that co-occur in Nebraska ponds.

Three major questions were addressed. Is Metamera sillasenorum host specific and if so, what are the factors influencing host specificity? Does the preferred prey item of $H$. triserialis serve as a mechanical vector for $M$. sillasenorum? Is a mechanical vector necessary for infection to occur? In order to address these questions, a survey of the 3 species of leeches and their gregarine fauna was conducted. Experiments were conducted to determine if the preferred prey served as a necessary mechanical vector for the parasite.

\section{MATERIALS AND METHODS}

\section{Animal collection and maintenance}

Leeches were collected during the summer months (May-August) of 1995-1998 from various ponds in Keith County, Nebraska. Helobdella triserialis were collected from Nevens Pond (Sec. 2, T14N R36W; N41 ${ }^{\circ} 12^{\prime} 26^{\prime \prime}, \mathrm{W} 101^{\circ} 25^{\prime} 7^{\prime \prime}$ ) in 1995, Buckhorn Springs Pond (Sec. 6, T14N R36W; N41 ${ }^{\circ} 12^{\prime} 38^{\prime \prime}, \mathrm{W} 101^{\circ} 29^{\prime} 24^{\prime \prime}$ ), Dunwoody Pond, (Sec. 32, T15N R37W; N41 ${ }^{\circ} 13^{\prime} 58^{\prime \prime}, \mathrm{W} 101^{\circ} 34^{\prime} 43^{\prime \prime}$ ), and from Martin Bay Pond

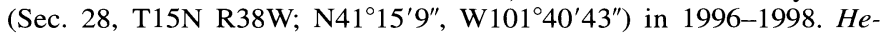
lobdella stagnalis were collected from Nevens and Martin Bay ponds. Leeches were maintained as 5-15 individuals of the same species and state of infection in small round plastic containers $(5 \mathrm{~cm}$ diameter $\times 5$ $\mathrm{cm}$ deep) filled with aged tap water from aquaria. The best food source was determined by adding both freshwater snails and oligocheates to containers with either $H$. triserialis or $H$. stagnalis. After food preferences were determined, $H$. triserialis were fed on a diet of the pulmonate snails of the genera Physa and Gyraulus; $H$. stagnalis were fed freshwater oligochaetes, Lumbriculus variegatus, 3 times a week. Snails were collected from Nevens, Dunwoody, Buckhorn Springs, and Martin Bay ponds and maintained in 38-L aquaria. Snails from sites where leeches were found to be infected were maintained separately from snails collected at sites with no infected leeches. The snails were fed 
boiled lettuce and Tetramin ${ }^{\circledR}$ fish food once/week. Lumbriculus variegatus, obtained from Carolina Biological Supply Company (Burlington, North Carolina), were fed fish food once/week and kept in plastic containers $(15 \mathrm{~cm} \times 30 \mathrm{~cm} \times 8 \mathrm{~cm}$ deep), lined with paper towels, and filled with aged tap water.

\section{Leech dissection and parasite observation}

Prior to leech dissection, leeches were measured while in an extended position, then divided into 2 size classes, $\geq 8 \mathrm{~mm}$, that were somewhat opaque although gregarines were still visible through the body, and $<8$ $\mathrm{mm}$, that were translucent, allowing the gregarines to be seen easily. Over the 3-yr period in which leeches were collected, $253 \mathrm{H}$. triserialis $(\geq 8 \mathrm{~mm}), 46 \mathrm{H}$. triserialis $(<8 \mathrm{~mm}), 45 \mathrm{H}$. stagnalis, and $15 \mathrm{G}$. complanata were dissected to determine prevalence and intensity of $M$. sillasenorum (survey leeches). Forty-three $H$. triserialis from Martin Bay Pond were dissected before infection experiments were conducted (Time zero controls). The leeches were minced in water or leech saline (Ramamurthi, 1969) solution $(67.0 \mathrm{mM} \mathrm{NaCl}, 11.2 \mathrm{mM} \mathrm{KCl}, 6.0 \mathrm{mM}$ $\mathrm{CaCl}_{2}, 4.0 \mathrm{mM} \mathrm{MgCl}$ ) and examined for parasites. Lengths and widths of gregarine protomerites and deutomerites of 692 trophozoites were measured under $\times 10$ using an ocular micrometer. The diameter of 25 gametocysts dissected from the gut also was measured. Additional detailed measurements from 43 trophozoites dissected in leech saline were made using videomicroscopy (Microimage Video System YC/NTSC, AutomatiCam A106; World Video Sales, Inc., Boyertown, Pennsylvania) and measured with a ruler calibrated to the television screen by use of a stage micrometer. The dimensions included were those of Clopton (1999). All measurements are in micrometers denoted as range (mean, standard deviation, number of observations). Descriptive terminology used for the epimerite and oocysts is consistent with recommendations of the Systematics Association Committee for Descriptive Biological Terminology (Anonymous, 1962a, 1962b).

Permanent mounts of gregarines were made by first allowing unadulterated gut smears to air dry only enough to prevent gregarines from draining off the slide. Slides were placed in Semichon's acid carmine for $3 \mathrm{~min}$, after which they were dehydrated through an alcohol series, cleared in xylene, and mounted in Canada Balsam (Clopton, 1998).

Gametocysts shed by $H$. triserialis were observed and collected daily from the containers housing infected leeches, then isolated into well plates filled with tap water, placed in a moist chamber, and monitored daily for oocyst production. After dehiscence, oocysts were pipetted onto a slide and a $9-\mathrm{mm}$ by $9-\mathrm{mm}$ coverslip placed on top. To view the oocysts using oil immersion, gelatin was added along the edges of the coverslip and allowed to cool. The length and height of 80 oocysts and the residuum dimensions of 30 additional oocysts were made using videomicroscopy.

\section{Experimental infections}

Leeches used in experiments were maintained separately from those dissected for survey purposes. Uninfected $H$. triserialis (Martin Bay Pond) and $H$. stagnalis (Nevens Pond) were held separately from each other and from the infected stock.

Three experiments were conducted using $H$. triserialis and $H$. stagnalis. In all 3, the control group included 8 plastic containers, each filled with water from Martin Bay Pond (where all leeches were uninfected), 1 uninfected $H$. triserialis and 1 uninfected $H$. stagnalis. Control leeches were fed unexposed snails from Martin Bay Pond or laboratory-reared L. variegatus worms. Experiment I differed from controls in that leeches were fed snails from Buckhorn Springs pond (snails exposed to oocysts) and laboratory-reared $L$. variegatus. In Experiment II, containers were filled with water that had previously held infected H. triserialis leeches and that had been observed to have contained gametocysts (exposed water). The leeches initially infected were removed, and uninfected leeches were then added and fed unexposed snails. Experiment III differed from Experiment II in that leeches were first placed in exposed water, then removed and placed into uncontaminated water and fed unexposed snails, then finally returned to the exposed water. Leeches from the 3 experiments were dissected 1 mo postexposure.

Two additional experiments were conducted using $H$. stagnalis. In Experiment IV, $15 \mathrm{H}$. stagnalis were placed in exposed water, to which was added 20 additional gametocysts that then sporulated, producing an estimated 60,000 oocysts. The leeches were fed unexposed $L$. variegatus worms for $3 \mathrm{wk}$ prior to dissection. In Experiment V, L. variegatus were placed in exposed water and allowed to remain for $1 \mathrm{wk}$ before 15 uninfected $H$. stagnalis were added. These experimental leeches were also dissected 1 mo postexposure.

In Experiment VI, G. complanata leeches were experimentally exposed to oocysts. Three $G$. complanata were placed in exposed water and fed exposed snails from Buckhorn Springs pond; 2 G. complanata, the controls, were placed in unexposed water and fed unexposed snails. One month later, the 3 experimental leeches were dissected. After this dissection, the 2 control G. complanata were fed exposed snails for 3 wks then dissected (Experiment VII).

To determine if snails could serve as mechanical vectors, laboratoryreared Physa sp., 3-5 mm long, were placed in vials with sporulated gametocysts for $24 \mathrm{hr}$, then removed and placed into clean water. Subsequently, snail feces were examined in fresh smears to determine whether oocysts could pass through the digestive system unharmed. Results were recorded by photography and videomicroscopy.

\section{Statistics}

The statistical program FieldStat (Clopton and Janovy, 1991) was used to analyze measurements of gametocysts, oocysts, and trophozoites. Contingency tables were used to compare the prevalence among the $3 \mathrm{yr}$ in which the study took place and to compare the prevalence of infection in $H$. triserialis among the 3 methods of experimental infection. Prevalence data were also subjected to a random allocation analysis in which 1,000 sets of 75,139 , and 39 were drawn from a pool with 198 infected and 55 uninfected leeches, and the probability of obtaining the observed prevalences calculated. Only leeches longer than $8 \mathrm{~mm}$ were included in the surveys and experiments. A $2 \times 2$ contingency table was used to compare prevalence in the 2 size classes. Linear regression was used to determine if a positive correlation existed between the size of the gregarines and the size of the leech host; results are reported as $r$ and $F=$ variance due to regression/variance about regression.

\section{DESCRIPTION}

Metamera sillasenorum $\mathbf{n}$. sp.

(Figs. 1-6)

\section{Taxonomic summary}

Diagnosis: Metameridae with characters of the genus Metamera Duke, 1910. Epimerite (withdrawn from gut epithelium) subconical, eccentric, with many branced digitiform processes at the base; gametocysts release oocysts by simple rupture; oocysts biconical, navicular; in leeches.

Trophozoites (Figs. 1-3, 5 and 6): Solitary, both attached and free in the gut diverticula of host. Deutomerites rarely seen with secondary segmentation. Epimerite (not attached to epithelium) depressed ovate with a collar of finger-like processes at the base. Size of living nonassociated trophozoites measured with an ocular micrometer: total length, not including the epimerite (TL) 90-550 (290, 83.7, 692); protomerite length (LP) 20-140 (61.7, 18.9, 692); protomerite width (WP) 30-110 $(56.4,13.2,692)$; deutomerite length (LD) 60-460 (228.9, 19.3, 692); deutomerite width at widest (WD) 20-260 (57.8, 19.3, 692). Ratios of measurements: LP/LD $0.11-0.55(0.28,0.06,692)$; LP/TL $0.09-0.35$ $(0.22,0.04,692)$; LD/TL $0.65-0.90(0.78,0.04,692)$; WP/WD $0.19-$ $1.75(0.99,0.14,692)$. Size of living nonassociated trophozoites measured with videomicroscopy: TL 154-407 (274.5, 62.5, 43), LP 33-94 $(59.8,17.2,43)$, protomerite length at anterior widest (PLA) 20-93 $(54.1,19.5,43)$, protomerite length at posterior widest (PLP) 0-55 $(5.69,14.4,43)$, WP $33-64(48.5,8.7,43)$, protomerite width at septum (SW) 34-58 (46.1, 7.6, 43), LD 114-313 (214.7, 48.4, 43), deutomerite length at anterior widest (DLA) 20-145 (87.1, 32.9, 43), deutomerite length at equator (DLE) 57-157 (107.4, 24.2, 43), deutomerite length at posterior widest (DLP) 45-245 (127.7, 48.9, 43), WD 30-65 (50.3, $8.3,43$ ), deutomerite width at equator (DWE) 35-65 (47.1, 7.3, 43), nucleus length (NL) 11-30 (20.1, 3.9, 43), nucleus width (NW) 17-32 $(23.4,3.7,43)$, epimerite length (EL) 11-20 (14.4, 38.8, 13), epimerite width (EW) 22-54 (31.5, 94.5, 13).

Gametocysts: Gametocysts spherical with a translucent mucus-like 


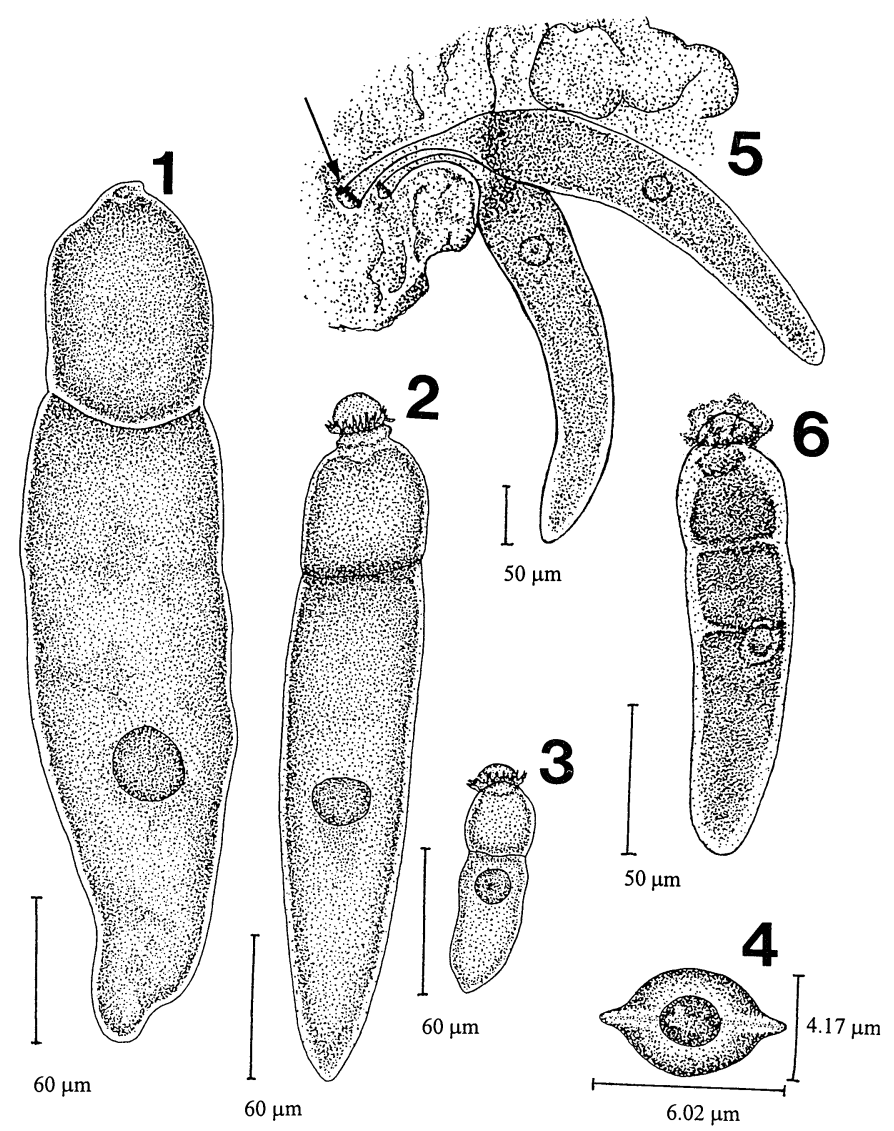

FIGURES 1-6. Metamera sillasenorum n. sp. 1. Large mature trophozoite (gamont) without epimerite. 2. Mature trophozoite with epimerite. 3. Young trophozoite with epimerite. 4. Oocyst with height and width indicated. 5. Attached trophozoites showing extended protomerites with epimerites (finger-like projections noted with arrow) in the gut epithelium of Helobdella triserialis. 6. Trophozoite exhibiting secondary segmentation of the deutomerite.

covering, diameter 110-160 (132.7, 12.2, 25). Dehiscence occurring by simple rupture approximately 3 days after isolation, releasing oocysts. After dehisence, liberated oocysts remain clumped, held together by an adhesive substance.

Oocysts (Fig. 4): Biconical, navicular with peglike ends; oocyst length (OL) 5-7 $(6.02,2.71,80)$, oocyst height $(\mathrm{OH}) 3.5-4.5$ (4.17, $0.17,80)$, oocyst shoulder height $(\mathrm{SH}) 0.2-0.3(0.20,0.02,30)$, residuum length (RDL) 1.2-3.2 (2.28, 0.45, 30), residuum height (RDH) 1.4-2.2 (1.80, 0.24, 30).

Type host: Helobdella triserialis (Blanchard, 1849). Voucher specimen deposited in the Smithsonian National Museum of Natural History, accession number 1043483, catalog number USNM 186411.

Infection site: Trophozoites were observed primarily in the leech intestinal ceca.

Type locality: Dunwoody Pond (N41 ${ }^{\circ} 13^{\prime} 58^{\prime \prime}, \mathrm{W} 101^{\circ} 34^{\prime} 43^{\prime \prime}$; Sec. 32, T15N R37W) Keith County, Nebraska.

Etymology: The specific epithet, sillasenorum, is named in honor of Jim and Lee Sillasen and their families. The first local record of $M$. sillasenorum was from leeches collected at Nevens Pond, owned by Jim Sillasen. The Sillasens have allowed students and faculty of Cedar Point Biological Station to use their land for over a decade.

Type specimens deposited: Holotype deposited in the H. W. Manter Laboratory of Parasitology, University of Nebraska State Museum, UNSM/HWML no. 39726; paratypes (4 slides) HWML no. 39727.

\section{Remarks}

The distinguishing morphological characteristic of the Metameridae Levine, 1979 is secondary segmentation of the protomerite and deutom- erite; the type genus is Metamera Duke, 1910. Duke (1910) reported that secondary segmentation of the deutomerite in the type species of Metamera, M. schubergi, occurred only occasionally. The other species in this genus, $M$. reynoldsi, evidently lacks secondary septa, yet is still considered a species of Metamera because of many other shared characteristics such as oocyst and epimerite shapes (Jones, 1943). Metamera sillasenorum not only shares the characteristic oocyst and epimerite shapes of Metamera but also exhibits secondary segmentation very rarely. Secondary segmentation was seen only in 2 gregarines of all those measured.

The epimerite of all 3 Metamera species has a collar of digitiform projections at the base when the gregarine is free of the gut epithelium. Differences in the shape of the epimerite exist among the 3 species. For example, in the original genus description, Duke (1910) described and illustrated an epimerite that he termed "subconical and eccentric"; Jones (1943) described the shape as a flat disc and did not mention eccentricity. The epimerite of $M$. sillasenorum is depressed ovate in profile and sometimes eccentric, but not consistently. Observed in fresh dissections when still attached to the gut epithelium, the $M$. sillasenorum protomerite is a long slender projection, approximately $120 \mu \mathrm{m}$ in length (Fig. 5). During detachment from the epithelium, the protomerite contracts into the shape described previously. In a typical leech dissection, virtually all measureable gregarines become detached from the gut epithelium. Thus, in the absence of observed associations or other life cycle data, there are no reliable criteria for distinguishing between trophozoites and mature gamonts.

Oocysts have a similar biconical shape among the 3 species but differ in measurements. Oocysts from all 3 species show peglike projections on the ends, but also differ in the size and shape of these projections. The failure to observe gamont association not only in this study, but also in those of Duke (1910) and Jones (1943), indicates similar lifecycle patterns among the 3 species.

Metamera sillasenorum can be distinguished from $M$. schubergi and $M$. reynoldsi by differences in size of the trophozoites, gametocysts, and oocysts. The trophozoites of $M$. sillasenorum are intermediate in shape and size between the 2 other species. Metamera schubergi is short and stout with a total length-to-protomerite length ratio of $4: 1$, with a total length of $150 \mu \mathrm{m}$ and width of $45 \mu \mathrm{m}$. Metamera reynoldsi is long and thin with a ratio of $6: 1$, total length $300 \mu \mathrm{m}$ and width 30 $\mu \mathrm{m}$. Metamera sillasenorum falls in between these 2 with a ratio of 5 : 1 , total length $285 \mu \mathrm{m}$ and width $57 \mu \mathrm{m}$ (average of mean total length from ocular measurements and videomicroscopic measurements) (Fig. 2 ). Student's $t$-tests revealed no significant difference in total lengths between the 692 specimens measured by ocular micrometer and the 43 measured using videomicroscopy. Metamera schubergi oocysts are relatively large $(9 \mu \mathrm{m}$ by $7 \mu \mathrm{m}), M$. reynoldsi oocysts are smaller and narrower $(5 \mu \mathrm{m}$ by $3 \mu \mathrm{m})$, and $M$. sillasenorum oocysts are intermediate between the 2 , with a length of $6.0 \mu \mathrm{m}$ and height of $4.2 \mu \mathrm{m}$. The peglike projections of the oocysts from $M$. sillasenorum are more pronounced than those of either $M$. reynoldsi or $M$. schubergi.

Metamera sillasenorum was not found in the few dissected G. complanata, although the latter co-occurs with the type host, $H$. triserialis, in the type locality. The other leech species from which $M$. schubergi has been recorded, $H$. marginata, was not found at any of the sampling sites.

\section{RESULTS}

\section{Parasite ecology}

In natural populations, only $H$. triserialis was infected with M. sillasenorum (Table I), though G. complanata was exceedingly rare and only 15 were examined. The prevalence of $M$. sillasenorum in $H$. triserialis was independent of collection year. Prevalence in leeches $\geq 8 \mathrm{~mm}$ for 1995 was $78 \%, 78 \%$ for 1996, and 79\% for 1997 (Table I; $\chi^{2}=1.57$, df $=2, P$ / independence/ $=0.48$; by random allocation method, P/independencel $=0.26$ ). Prevalence in leeches $<8 \mathrm{~mm}$ was $17 \%$ for 1996 and 30\% for 1997 (Table II; $\chi^{2}=0.73$, df $=1$, P/independencel $=0.45$; by random allocation method, P/independencel $=0.45$ ). Prevalence in leeches $\geq 8 \mathrm{~mm}$ for 1996 and 
TABLE I. Prevalence of Metamera sillasenorum in the leeches Helobdella triserialis $(\geq 8 \mathrm{~mm})$ and Helobdella stagnalis and Glossiphonia complanata in Keith county, Nebraska 1995-1997 (collection sites pooled).

\begin{tabular}{llccc}
\hline \multirow{2}{*}{ Year } & \multicolumn{1}{c}{ Species } & $\begin{array}{r}\text { No. hosts } \\
\text { examined }\end{array}$ & $\begin{array}{c}\text { No. hosts } \\
\text { infected }\end{array}$ & $\begin{array}{c}\text { Prevalence } \\
(\%)\end{array}$ \\
\hline \multirow{1}{*}{1995} & H. triserialis & 75 & 59 & 78 \\
& H. stagnalis & 15 & 0 & 0 \\
& G. complanata & 9 & 0 & 0 \\
& H. triserialis & 139 & 108 & 78 \\
& H. stagnalis & 15 & 0 & 0 \\
& G. complanata & 1 & 0 & 0 \\
& H. triserialis & 39 & 31 & 79 \\
& H. stagnalis & 15 & 0 & 0 \\
& G. complanata & 5 & 0 & 0 \\
\hline
\end{tabular}

1997 (combined sample) was greater than that of leeches $<8$ $\mathrm{mm}\left(\chi^{2}=9.83, \mathrm{df}=1\right.$, P/independencel $=0.002$; by random allocation method, P/independence/ $=0.001)$. Neither gregarine infrapopulation nor gregarine size were correlated with leech length $(r=-0.105, F[1,102]=1.16$ and $r=0.042, F[1,646]$ $=1.13$ respectively).

\section{Experimental infections}

Before experimental infections were conducted, the mean number of gametocysts in a container on any given day was $2.3, \mathrm{SD}=1.66$, range $=1-9(\mathrm{n}=83)$. On average then, each leech shed a gametocyst every other day. Experiment $\mathrm{I}$, which involved using unexposed water and exposed snails as the food source, resulted in 12 of the $14 \mathrm{H}$. triserialis becoming infected (Table III). In Experiment II, which involved using snails from an unexposed pond as the food source with leeches in exposed water, 3 of the $8 \mathrm{H}$. triserialis were infected (Table III). Experiment III in which leeches were removed from exposed water in order to feed them unexposed snails in unexposed water, no infections were obtained (Table III). Successful infection of $H$. triserialis leeches is not independent of the method used $\left(\chi^{2}\right.$ $=12.46, \mathrm{df}=2 ;$ P/independencel $<0.005)$. When only Experiment I and Experiment II were compared, infection rate was not independent of method $\left(\chi^{2}=5.46\right.$, df $=1, P=0.02 ; P /$ independencel determined by the random allocation method was 0.03). Control groups and experiments with $H$. stagnalis did not yield infected leeches (Table III).

In Experiment IV involving exposed L. variegatus, none of the $14 \mathrm{H}$. stagnalis were infected (1 died during the 1-mo period). In Experiment $\mathrm{V}$, which concentrated the number of gametocysts to which leeches were exposed, none of $13 \mathrm{H}$. stagnalis leeches was uninfected ( 2 died).

TABLE II. Prevalence of Metamera sillasenorum in the leeches Helobdella triserialis $(<8 \mathrm{~mm}$ ) in Keith county, Nebraska 1995-1997 (collection sites pooled).

\begin{tabular}{llccc}
\hline Year & Species & $\begin{array}{c}\text { No. hosts } \\
\text { examined }\end{array}$ & $\begin{array}{c}\text { No. hosts } \\
\text { infected }\end{array}$ & $\begin{array}{c}\text { Prevalence } \\
(\%)\end{array}$ \\
\hline 1996 & H. triserialis & 6 & 1 & 17 \\
1997 & H. triserialis & 40 & 12 & 30 \\
\hline
\end{tabular}

TABLE III. Prevalence of Metamera sillasenorum in the leeches Helobdella triserialis and Helobdella stagnalis after experimental infection using 3 different methods.

\begin{tabular}{llccc}
\hline $\begin{array}{c}\text { Experi- } \\
\text { ment* }\end{array}$ & \multicolumn{1}{c}{ Species } & $\begin{array}{c}\text { No. hosts } \\
\text { examined }\end{array}$ & $\begin{array}{c}\text { No. hosts } \\
\text { infected }\end{array}$ & $\begin{array}{c}\text { Prevalence } \\
(\%)\end{array}$ \\
\hline I† & H. triserialis & 14 & 12 & 86 \\
& Control & 11 & 0 & 0 \\
& H. stagnalis & 10 & 0 & 0 \\
& Control & 9 & 0 & 0 \\
II $\neq$ & H. triserialis & 8 & 3 & 38 \\
& Control & 8 & 0 & 0 \\
& H. stagnalis & 6 & 0 & 0 \\
III§ & Control & 8 & 0 & 0 \\
& H. triserialis & 5 & 0 & 0 \\
& Control & 5 & 0 & 0 \\
& H. stagnalis & 6 & 0 & 0 \\
& Control & 5 & 0 & 0 \\
\hline
\end{tabular}

* Controls in all cases: uninfected leeches + unexposed snails + unexposed water. $\dagger$ Experiment I: uninfected leeches + exposed snails + unexposed water. $\$$ Experiment II: uninfected leeches + unexposed snails + exposed water.

$\S$ Experiment III: uninfected leeches + gametocysts + exposed water, leeches removed for feeding on unexposed snails.

Experiment VI, using G. complanata, resulted in no infections. The 2 leeches used as a control in Experiment VI were later used in Experiment VII, and neither became infected. In snail-feeding experiments, intact oocysts could regularly be observed in snail feces (Fig. 7).

\section{DISCUSSION}

Beyond the species description, the major contribution of this study is the demonstration that snails are essential for transmission of a host-specific parasite. The strength of this ecological linkage between $M$. sillasenorum, $H$. triserialis, and snails is shown best by Experiment III, in which leeches living in water with oocysts but removed for feeding, did not become infected. The food source, especially invertebrates, as the mode of transmission is documented in many host-parasite relation-

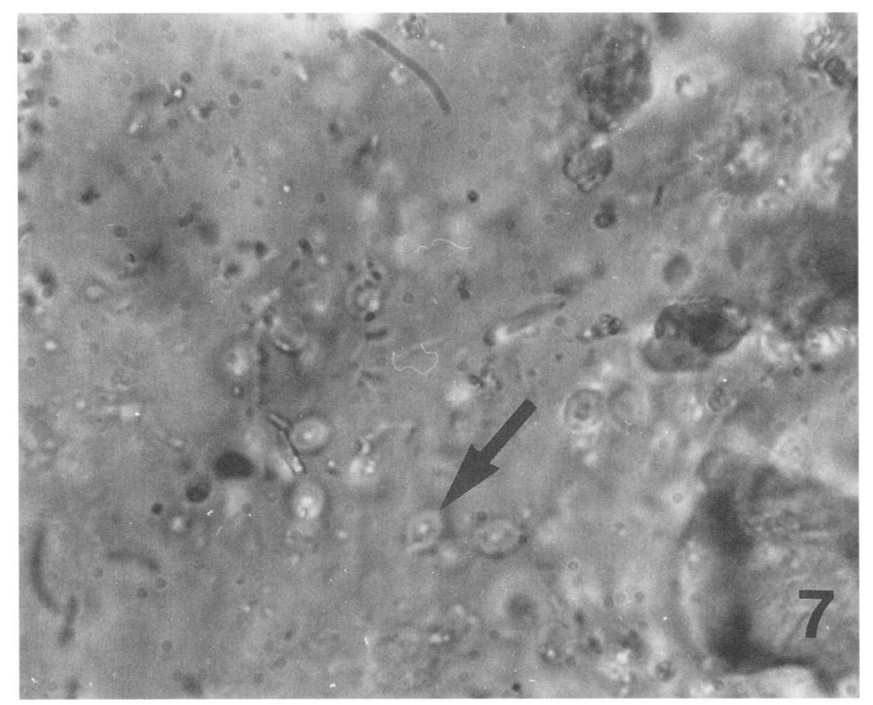

FIGURE 7. Metamera sillasenorum n. sp. Oocysts in fecal material from a freshwater snail Physa sp. 
ships. Åbro (1976) showed a gregarine oocyst attached to the hairs on the legs of an aquatic insect and concluded that although only 1 in 200 larvae had oocysts attached to the legs, the larvae served as the main source of infection in the damselfly hosts. Other apicomplexans such as Toxoplasma gondii and Goussia subepithelialis can use dung beetles and aquatic oligochaetes as paratenic hosts, respectively (Saitoh and Itagaki, 1989; Paperna, 1995). Differences in food preferences between $H$. triserialis and $H$. stagnalis may have played a role in the initial establishment of host specificity, but under the experimental conditions $H$. stagnalis should have consumed enough oocysts to become infected. At least some $G$. complanata should also have become infected under the experimental conditions if $M$. sillasenorum was not host specific, given the nature of the leeches' preferred food, e.g., snails and given that under the same exposure conditions 12 out of $14 \mathrm{H}$. triserialis became infected. Thus, feeding habits alone are probably not the limiting factor in $M$. sillasenorum host specificity. Although the snail is evidently not required for parasite development, the fact that $M$. sillasenorum both exploits and depends upon an established trophic relationship between host and preferred prey illustrates 1 of the ways in which a complex life cycle can evolve.

Prevalence of $M$. sillasenorum in $H$. triserialis did not differ significantly between years, indicating that the annual variations in weather did not affect prevalence. Past studies have hypothesized or shown positive correlation between size of host and numbers of parasites (Price, 1990; Keymer et al., 1991; Guégan et al., 1992; Watve and Sukumar, 1995). In the present study, leech size influenced prevalence of $M$. sillasenorum. Leeches longer than $8 \mathrm{~mm}$ had a higher prevalence than leeches shorter than $8 \mathrm{~mm}$. As past studies have suggested, a possible explanation for this phenomenon is that larger hosts consume more food (Keymer et al., 1991; Watve and Sukumar, 1995). The supposedly greater food intake by larger hosts does not entirely explain why this relationship exists. For example, small leeches still attached to the mother feed from the same snail as the mother; hence, one would expect that if the mother becomes infected, all of the attached young should become infected. Infected leeches still attached to their mother were seen in 2 instances during the past $3 \mathrm{yr}$, but on those occasions, only 1 attached leech in a group of 15 was infected.

The present study provided information to answer fully 2 of the 3 questions asked and to begin answering the third. The preferred prey item of $H$. triserialis does serve as a mechanical vector for $M$. sillasenorum. Although a mechanical vector is not absolutely necessary for infection to occur, it is most likely the significant source of infection in an $H$. triserialis population. Metamera sillasenorum appears to be host specific based on the experimental infections and field observation. Further studies using the North American and European G. complanata could provide more conclusive evidence for determining host specificity of $M$. sillasenorum.

\section{ACKNOWLEDGMENTS}

We thank Cedar Point Biological Station for the use of facilities, Richard E. Clopton for helpful gregarine handling hints,
William Moser for assistance with leech identification, and Mark Siddall for statistical analysis suggestions. This study was funded in part by the Ashton C. Cuckler Fellowship to M.R.W.

\section{LITERATURE CITED}

ÅBRO, A. 1976. The mode of gregarine infection in Zygoptera (Odonata). Zoologica Scripta 5: 265-275.

ANonymous. 1962a. Systematics Association Committee for Descriptive Biological Terminology. II. Terminology of simple symmetrical plane shapes (Chart 1). Taxon 11: 145-155.

- 1962b. Systematics Association Committee for Descriptive Biological Terminology. IIa. Terminology of simple symmetrical plane shapes (Chart 1a). Taxon 11: 245-247.

Bhatia, B. L., and S. B. Setna. 1938. On some gregarine parasites from certain polychete worms from the Andaman islands. Proceedings of the Indian Academy of Sciences Section B 8: 231-242.

Clopton, R. E. 1998. Revision of the genus Torogregarina and description of Torogregarina sphynx n. sp. (Apicomplexa: Eugregarinida) from a Missouri River bank beetle, Bembidion laevigatum (Coleoptera: Carabidae), in southeastern Nebraska. Journal of Parasitology 84: 823-827.

- 1999. Revision of the genus Xiphocephalus and description of Xiphocephalus ellisi n. sp. (Apicomplexa: Eugragarinida: Stylocephalidae) from Eleodes opacus (Coleoptera: Tenebrionidae) in the western Nebraska sandhills. Journal of Parasitology 85: 84-89

, AND J. JaNOVy, JR. 1991. FieldStat statistical package. Hotel Intestine Software, Lincoln, Nebraska.

Cognetti de Martis, L. 1911. Descrizione d'una nuova gregarina Policistidea parassita d'un oligochete. Archiv für Protistenkunde 23: 247-252.

DUKE, H. L. 1910. Some observations on a new gregarine (Metamera schubergi nov. gen., nov. spec.). Quarterly Journal of Microscopical Science 55: 261-286.

Ganapati, P. N., C. Kalavati, and P. S. Sundaram. 1974. On a new multisegmented gregarine, Gopaliella marphysae n. gen., sp. from the gut of a polychaete worm, Marphysa gravelyi. Archiv für Protistenkunde 116: S244-S250.

Guégan, J. F., A. Lambert, C. Lévêque, C. Combes, and L. Euzet. 1992. Can host body size explain the parasite species richness in tropical freshwater fishes? Oecologia 90: 197-204.

JONES, A. W. 1943. Metamera reynoldsi n. sp., a cephaline gregarine from the leech, Glossosiphonia complanata. Transactions of the American Microscopical Society 62: 254-258.

Keymer, A. E., R. D. Gregory, P. H. Harvery, A. F. Read, and A. SKORPING. 1991. Parasite-host ecology: Case studies in population dynamics, life-history evolution and community structure. Acta Ecologica 12: 105-118.

LEVINE, N. D. 1979. New genera and higher taxa of septate gregarines (Protozoa, Apicomplexa). Journal of Protozoology 26: 532-536.

PAPERNA, I. 1995. Ultrastructural and developmental affinities of piscine coccidia. Diseases of Aquatic Organisms 22: 67-76.

PRICE, P. W. 1990. Host populations as resources defining parasite community organization. In Parasite communities: Patterns and processes, G. Esch, A. Bush, and J. Aho (eds.). Chapman and Hall, London, U.K., p. 21-40.

RAMAMURTHI, R. 1969. Oxygen consumption of the common Indian cattle leech Poecilobdella granulosa in relation to osmotic stress. Comparative Biochemistry and Physiology 24: 283-287.

SAITOH, Y., AND H. ITAGAKI. 1990. Dung beetles, Onthophagus spp., as potential mechanical vectors of feline coccidia. Japanese Journal of Veterinary Science 52: 293-297.

Watve, M. G., AND R. Sukumar. 1995. Parasite abundance and diversity in mammals: Correlates with host ecology. Proceedings of the National Academy of Sciences USA 92:8945-8949. 